\title{
EFFECT OF TRIDAXPROCUMBENS EXTRACTS ON BLOOD CLOTTING
}

\author{
ATCHADE S. PASCAL, HOTEYI ISMAEL, SEIBOU TOLEBA SOUMANOU, BELLO KAOKAB, SEZAN ALPHONSE*
}

Laboratory of Biomembranes and Signalling Cell/University of Abomey-Calavi, Benin

Email: sezco@live.fr

Received: 15 Oct 2018, Revised and Accepted: 10 Dec 2018

\begin{abstract}
Objective: The present work has focused on evaluating the effect of tridaxprocumbens on blood clotting.

Methods: in the course of our study we have therefore carried out a Hydro ethanol extraction (50/50), Liquid-Solid extraction, and phytochemical screening. Thereafter our study was carried out on nine (09) male and female Wistar type rats aged from 10 to $12 \mathrm{w}$ and weighing between 100 and $200 \mathrm{~g}$. These animals were raised at the laboratory of Biomembranes Laboratory and Cell Signaling from FAST to UAC under standard environmental conditions. Animals have free access to water and food. 09 rats are experienced, divided in three batches of 3 rats each, submitted respectively to the following treatment: fed with distilled water, fed with $100 \mathrm{mg} / \mathrm{kg}$ P. C tridax extract procumbens, fed at $300 \mathrm{mg} / \mathrm{kg}$ P. C tridax extract procumbens. Evolution of the weight of rats during treatment was measured. After $7 \mathrm{~d}$ of treatment, the blood of the rats is taken for an experience of bleeding time, experience of coagulation time, and dosage of some blood parameters (platelet, partial thromboplastin, prothrombin).
\end{abstract}

Results: Phytochemical screening carried out on the leaf and stem powder of Tridaxprocumbens revealed the presence of phenolic compounds, flavonoids, reducing sugar, mucilage, terpene and sterol, but at varying proportions. After $7 \mathrm{~d}$ of treatment, evaluation of the effect of the extractions on the body weight of the rats gave interesting conclusions. The weight of the control rats did indeed increase while that of the rats treated with the dose of $(100$ and $300 \mathrm{mg} / \mathrm{kg})$ dropped. In addition, the effect of the hydroethanolic extract of the leaves and stems of Tridaxprocumbens on the coagulation of blood has been studied in order to verify the alleged property that the said extract can be used to manage bleeding. This was done by examining the effect of the extract on bleeding time, coagulation time, platelet count, activated partial thromboplastin time and prothrombin rate. These were carried out using the Duke method and the Lee and White method. In the bleeding time experiment, the mean time without adding the extract was $2.58 \pm 0.31 \mathrm{~min}$, while the mean bleeding time after treatment with the extract was $1.61 \pm 0.70 \mathrm{~min}$ at a dose of $100 \mathrm{mg} / \mathrm{kg} \mathrm{PC}$ and $1.77 \pm 0.69 \mathrm{~min}$ at a dose of $300 \mathrm{mg} / \mathrm{kg}$ PC, achieving $57 \%$ of the decrease in normal bleeding time. Thus the extract significantly lowers the bleeding time.

When the extract was used for the coagulation time, it was found that the extract promotes blood clotting. In addition, this study reveals that Tridaxprocumbens significantly influences TCA, TP and platelet count at varying doses.

Conclusion: The plant material studied in this study is, therefore, a credible alternative for an effective fight against bleeding and also promotes the coagulation of blood.

Keywords: Tridaxprocumbens, Phenolic compounds, Coagulation, TS, TP, TC, TCA, and Platelet count

(c) 2019 The Authors. Published by Innovare Academic Sciences Pvt Ltd. This is an open access article under the CC BY license (http://creativecommons.org/licenses/by/4.0/) DOI: http://dx.doi.org/10.22159/ijcpr.2019v11i1.31992

\section{INTRODUCTION}

Plants have long played a very important role in the evolution of humankind, they can synthesize a large number of complex organic molecules with often potential biological activities. They are wonderful plant seedlings that give us the joy of healing with a therapeutic gesture [1-2]. It is used traditionally to heal, relax, flavor food and preserve food etc.

Until today, the popular use of plants remains of great importance. According to the WHO (World Health Organization), $80 \%$ of the world's population treat their health problems by traditional remedies, because they often do not have access to medicines prescribed by modern medicine and, secondly, because these plants are often very effective [3]. Indeed, the majority of current medicines are of origin or made from their models (synthesis or chemical semisynthesis of active ingredients). Herbal medicine has become a great science, in which we start from the plant to the active ingredient.

In West Africa, as in the rest of the continent, more than $80 \%$ of the population uses traditional medicine and medicinal plants for their primary health care. Lack of essential drugs, inadequate health care, the high cost of drugs and socio-cultural habits explain the use of traditional herbal practices [4]. In addition, the efficacy of recipes in the treatment of several pathologies makes them more interesting than modern synthetic molecules [5].

In this context, the use of medicinal plants as an alternative to modern medicine is not to be minimized. Knowing, improving and valuing the use of medicinal plants is an urgent and permanent need. In this regard, Tridaxprocumbens is one of the herbs used in the treatment of hyperthermia, typhoid fever, asthma, epilepsy, and diarrhea [6]. It is used for the treatment of bronchial catarrh, dysentery, malaria, diarrhea, hypertension, bruising [7]. Several researchers have reported that it has immunomodulatory properties [8], antidiabetic agents [9], antihepatotoxic, antioxidant [10], antimicrobials [11], antibacterial [12], antiplasmodium [13], and anti-cancer [14]. The hydroethanolic extract of T. Procumbens is a good antioxidant that significantly reduces the accumulation of hepatic lipids and stimulates their oxidation in HepG2 cells [15]. Several secondary metabolites in T. Procumbens extracts. In Benin, phytochemical screening revealed the presence of catechin tannin, flavonoid, mucilage and reducing sugar [16]. Similarly, a study report revealed the presence of triterpernoids, sterols, flavonoids, mucilages and reducing compounds [17].

The present work aims to evaluate the effect of tridaxprocumbens on blood clotting in Wistar rats. For this purpose the objectives of the work are formulated as follows:

The overall objective of this study is to evaluate the effect of tridaxprocumbents on the blood clotting in wistar rats.

\section{Generality}

Tridax procumbens

\section{Description botany}

From the family Asteraceae (sunflowers), Tridaxprocumbens is an annual species native to tropical America, introduced in the tropical, 
subtropical and temperate regions of the world. It is frequently found in fields, meadows, and roadsides in the tropics. Tridaxprocumbens is a spreading herbaceous plant whose flowering ends are ascending, its root is a powerful pivot (root that sinks vertically into the ground). The opposite leaves, simple and irregularly toothed, arrow-shaped; they are thick, soft and dark green in color. The leaves are bound by a petiole 1 to $2 \mathrm{~cm}$ long. The lamina is ovate to lanceolate, with a base attenuated in the wedge and irregularly toothed margin (fig. 1). The stem is cylindrical, full and strongly hispid, covered with multicellular white hairs of $1 \mathrm{~mm}$, tubercular at the base. The flowers are assembled in solitary heads. The flower heads at the end of long peduncles are composed of 4 to 7 cream-colored ligulate peripheral flowers and numerous yellow tubular flowers. In the center of the capitulum 10 to 30 yellow, tubular flowers that are hermaphroditic separated by membranous scales. The fruit of the plant is a hard conical achene covered with stiff hairs and surmounted feathery featheryfeathery. Tridaxprocumbens is propagated by seed but has a strong potential for cuttings especially in the rainy season. Although an annual species, the plant can be planted when regularly cut [18].

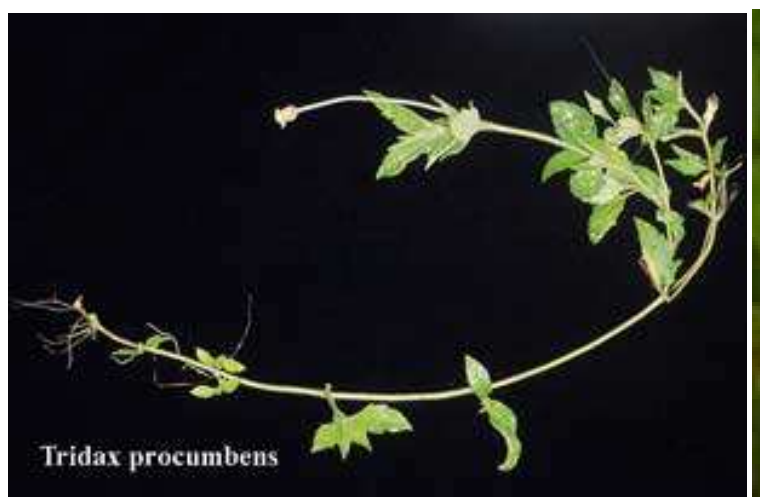

a) Stems and leaves

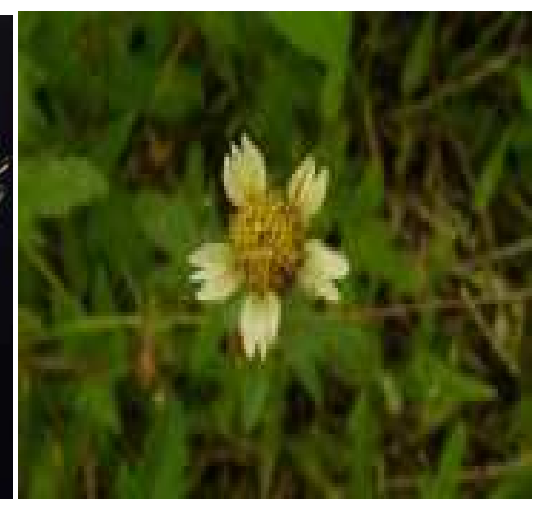

b) Flower

Fig. 1: Different parts of Tridaxprocumbens (K. BELLO)

\section{Use in traditional medicine}

Tridax procumbens is a plant with many virtues from which are used in traditional medicine. Thus, it is used in the treatment of many pathologies such as bronchial catarrh, dysentery, diarrhea, hair loss, jaundice [5-19-20]. Leaf sap is also used to treat fresh wounds and stop bleeding. The entire plant is used in Guatemala for the treatment of protozoan diseases such as malaria, leishmaniasis, dysentery and in the treatment of colic and gastroenteritis [21-22]. It is also used in West Africa to treat conjunctivitis [23]. In Nigeria, it is used against yellow fever, typhoid fever, asthma, cough, epilepsy, stomachaches, and diarrhea [6-24]. In Togo, the fresh leaves of T. procumbens are crushed and used for dressing the wounds; Leaf decoction is used orally to relieve abdominal pain and fungal infections and to treat malaria [25]. In traditional veterinary medicine, T. procumbens is also mentioned in plants for pharmacological use recognized and used by breeders in Africa [26]. In Benin, the plant is also widely used by pastoralists in the diet of several crops including cattle and rabbits [27-28].

\section{MATERIALS AND METHODS}

\section{Materials}

\section{Plant material}

The plant material consists of stems and leaves of Tridaxprocumbens.

\section{Animal material}

The experiments were carried out on adult male and female Wistar,strain weighing between 100 and 200 g. Upon receipt, the rats were randomly placed in groups of (3) in the standard cages for an acclimation period before being used in the different experiments. During this period, the animals had free access to food and water and remained in the animal laboratory of the biomembrane and cell signaling laboratory of the Department of Animal Physiology of the University of Abomey-calavi.

\section{Methods}

The phase of realization of the fractions of the leafy stems. It consisted:

\section{Harvesting, drying and grinding}

The leafy stems of Tridaxprocumbens were harvested in May 2017 in the commune of Abomey-Calavi. The flowers, the flower buds and the roots are separated from the leafy stems. The samples are dried for one month at laboratory temperature. They were then crushed using an electronic grinder and kept in jars.

\section{Hydro ethanol extraction (50/50)}

$100 \mathrm{~g}$ of powders of Tridaxprocumbens leaves are taken separately in three jars in $750 \mathrm{ml}$ of hydroethanol solution (50:50), ie $(375 \mathrm{ml}$ of ethanol/375 ml of distilled water) and stirred continuously for 24 h. The mixture is filtered using the bushner (the operation was repeated for $72 \mathrm{~h}$ ). The filtrate obtained is put in an oven to evaporate the ethanol. The dry extraction was finally recovered, weighed, labeled and stored at $4^{\circ} \mathrm{C}$ until use. Since it was necessary to calculate the yield of the plant, the extraction was made for $72 \mathrm{~h}$ to be sure to have recovered all the secondary metabolites.

\section{Liquid-solid extraction}

It consists of evaporating at a temperature according to the polarity solvents contained in the liquid-liquid extracts using a rotary evaporator. The extracting phase is collected and solidified under study.

\section{Animals and experimental conditions}

Our study was carried out on nine (09) male and female Wistar type rats aged from 10 to $12 \mathrm{w}$ and weighing between 100 and $200 \mathrm{~g}$. These animals were raised at the laboratory of Biomembranes Laboratory and Cell Signaling from FAST to UAC under standard environmental conditions. Animals have free access to water and food.

\section{Methods for evaluating coagulation parameters}

09 rats are experienced. They weigh between $100 \mathrm{~g}$ and $200 \mathrm{~g}$ and are divided into (3) lots of three (3) rats. The rats were acclimatized for three (3) weeks at the Laboratory of Biomembranes Laboratory and Cell Signaling.

-Batch 1: 3 rats, fed with distilled water. 
-Batch 2: 3 rats, fed with $100 \mathrm{mg} / \mathrm{kg}$ P. C tridax extract procumbens.

-Batch 3: 3 rats, fed at $300 \mathrm{mg} / \mathrm{kg}$ P. C tridax extract procumbens.

Day 0:

At 7am, weight gain and blood sample for the assay of different coagulation tests of all rats before any operation.

Day1: Batch feeding

-Batch 1: 3 rats, fed with distilled water.

-Batch 2: 3 rats, fed at $100 \mathrm{mg} / \mathrm{kg}$ of $\mathrm{P}$. C extract of tridaxprocumbens.

-Batch 3: 3 rats, fed at $300 \mathrm{mg} / \mathrm{kg}$ P. C tridax extract procumbens.

Day 07: Weight gain and force-feeding

Day 08: withdrawal

\section{Blood collection method}

The blood from the rats of lots (1-3) are all collected before treatment at $\mathrm{D}=0$. The blood sample is taken according to the experimental protocol used by [29], and modified by Descat in 2000[30]. Puncture of the retro-orbital sinus is performed under anesthesia (diethyl ether). The anesthetized animal is held in one hand in the lateral decubitus, and held by the skin of the neck. The pressure of the thumb on the neck, behind the angle of the jaw, will achieve compression of the jugular vein, and thus a venous stasis to the head, favoring the filling of the retro-orbital sinus. By making a slight pull on the upper eyelid with the index finger, we will create an exophthalmia facilitating the collection of blood using a non-heparinized hematocrit tube. The end of the tube is slowly introduced into the lateral angle of the eye. The progression through the tissues is facilitated by printing a slight rotation of the tube. As soon as one reaches the venous plexus, the blood gushed in the periorbital space and rises by capillary action in the tube. The volume of blood collected is approximately 1 to $2 \mathrm{ml}$ in EDTA tubes, citrate tubes, and dry tubes. Before removal of the tube, the compression is released and the bleeding stops spontaneously when the ocular pressure is normalized. The recovered blood is used for the determination of different parameters of hemostasis.

\section{Experience of bleeding time}

The bleeding time was carried out according to the method of DUKE, in which two healthy rats and two rats treated with a dose of 100 and $300 \mathrm{mg} / \mathrm{kg}$ of PC were used. One rat was taken at a time, the anterior surface of his cleanly shaved tail was carefully cleaned using cotton buffered in $70 \%$ ethanol and with disposable lancets $3 \mathrm{~mm}$ deep a laceration was done on the shaved tail. A drop of the preparation of the extract was delivered directly into the experimental laceration and a judgment was observed. The addition was made periodically and blotted using cotton until the bleeding stopped and the time taken for the bleeding to stop was recorded as the bleeding time. Another laceration was done on the tail of another rats to serve as a control and the above procedure was repeated but this time without adding the extract and the bleeding time was recorded. Both procedures were then repeated for the other rats

\section{Experience of the coagulation time}

This is a global test performed on whole blood. The blood is collected in dry glass tubes, rinsed with saline. 09 rats are experienced. They have a weight between $100 \mathrm{~g}$ and $200 \mathrm{~g}$ and divided into (3) lots of three (3) rats, their blood was collected in nine dry tubes. In each tube, $1 \mathrm{ml}$ of freshly drawn rat blood is stirred every minute at $37^{\circ} \mathrm{C}$, and the stopwatch is immediately started until complete coagulation. After a few minutes, the tubes were observed at 15-second intervals by tilting very gently to see if the blood had coagulated completely. Coagulation was considered complete when the tube could be reversed without significant movement of blood in the tube. The time taken by the blood coagulated in each tube was recorded and the procedure was repeated for the rest of the tubes.

\section{RESULTS AND DISCUSSION}

\section{RESULTS}

\section{Realization of fractions of tridaxprocumbens}

The yield of the different fractions obtained is calculated according to the formula:

$\mathrm{R}=($ Mass of the fraction $) /($ Mass of the powder $) \times 100$

Table 1: below shows the different yields of the fractionation

\begin{tabular}{ll}
\hline Solvent type & Extract yield in\% \\
\hline Hexane & 0,160 \\
Dichlorométhane & 0,073 \\
Ether-diéthylique & 0,093 \\
Acétate d'éthyle & 0,150 \\
\hline
\end{tabular}

These yields are consistent with those of Amagbegnon in 2017 [31], but very low compared to those of Koudoro et al. in 2014 [32] which by this method carried out on cochlospermumplanchoni root bark obtained
$0.8 \%$ and $1.5 \%$. \% for the respective fractions of diethyl ether and ethyl acetate. We believe that this difference in yield could be due to the duration of the mixing of the aqueous phase with the different solvents.

Table 2: Results of phytochemical screening phytochemical screening

\begin{tabular}{lll}
\hline Chemical compounds & & Leaf and stems of tridaxprocumbens \\
\hline alkaloids & Catechism tannins & - \\
& Gallic tannins & - \\
Polyphenolic compounds & anthocyanin & +++ \\
& Buffy antocyane & - \\
Quinone derivatives & & - \\
saponosides & \\
triterpenoids & \\
sterols & + \\
mucilage & + \\
coumarins & ++ \\
Reducing compounds & - \\
\hline
\end{tabular}

+: Low presence,++:strong presence,+++Very strong presence,-:Absence

The results obtained following the phytochemical screening of the leaves and stems of tridaxprocumbens are recorded in the table.
We thus note in the leaves a very strong presence of flavonoids, a weak presence of sterol, mucilage and a weak presence of terpene 
and a strong presence of reducing compounds this is in accordance with the results of Koukoui in 2015, andGanjuin 2013 [16-33]. By other research like that of Ikewuchi Jude et al., 2009 identified other phenolic compounds in TridaxProcumbens extracts such as alkaloids, tannins, carotenoids, saponosides [34].

Evolution of the weight of rats during treatment

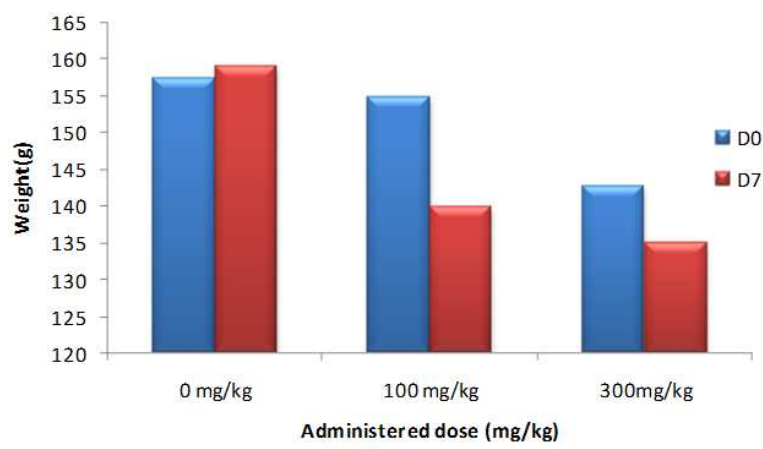

Fig. 2: Evolution of the weight of normal control rats and those treated with the hydroethanolic extract of the leaves and stems of tridaxprocumbens during $07 \mathrm{~d}$

We observed an increase of the weight in the control rats whereas the weight of the treated rats $(100$ and $300 \mathrm{mg} / \mathrm{kg}$ of PC) decreased. Tridaxprocumbens extracts could, therefore, be said to reduce slightly or prevent weight gain in rats. This may be due to the lipid-lowering effect [16] thus inhibiting the accumulation of fat in the adipose tissue.

\section{Determination of bleeding time}

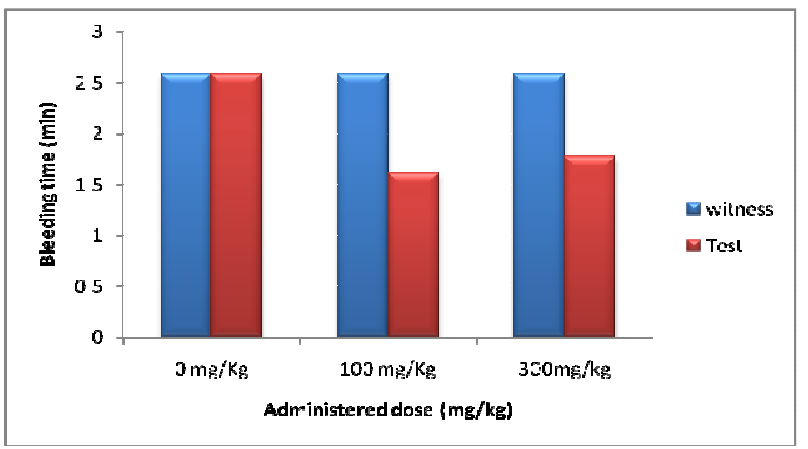

Fig. 3: Effect of tridaxprocumbens on bleeding time

Fig. 3, shows the results obtained from the bleeding time experiment. Determination of clotting time

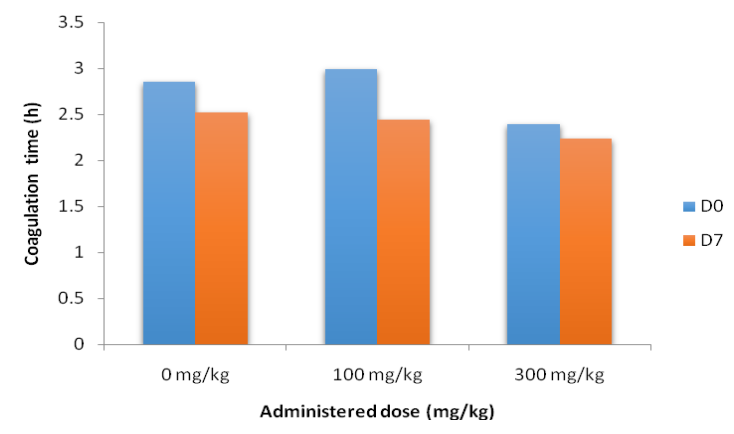

Fig. 4: Effect of tridaxprocumbens on coagulation time

Fig. 4, shows the results obtained from the coagulation time experiment. The clotting time decreased in all the rats treated with the extract.
Determination of platelet count

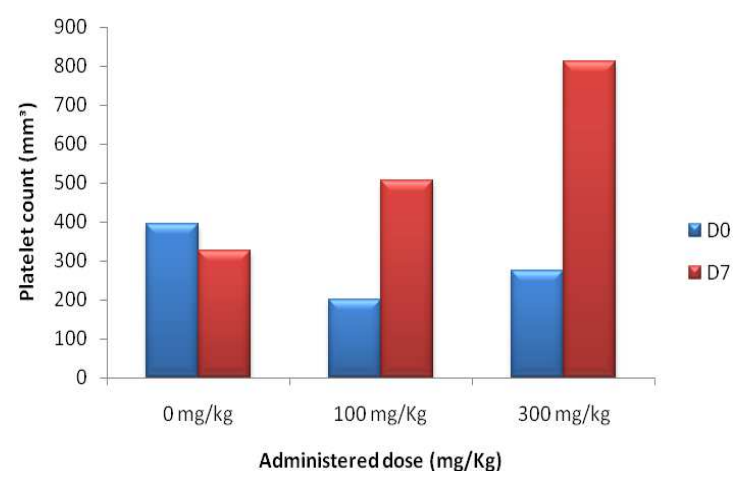

Fig. 5: Effect of tridaxprocumbens on platelet count

We can deduct from the interpretation of this fig. that the number of platelets has increased.

Determination of activated partial thromboplastin time (APTT)

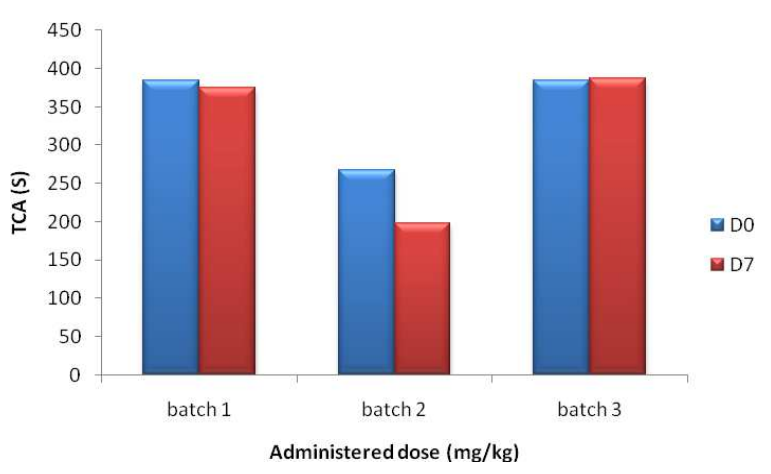

Fig. 6: Effect of tridaxprocumbens on activated partial thromboplastin time

\section{Determination of prothrombin levels (TP)}

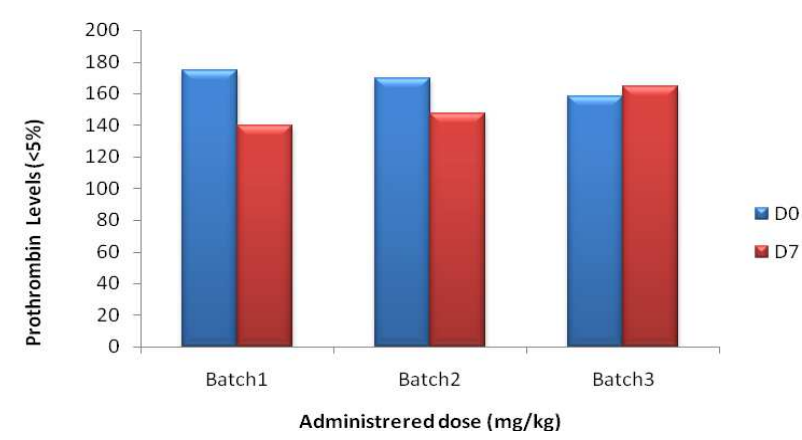

Fig. 7: Effect of tridaxprocumbens on the prothrombin rate

Fig. 7 shows the effect of tridaxprocumbens on the prothrombin rate.

\section{DISCUSSION}

TridaxProcumbens, commonly known as French rabbit herb and Azuiman or Hladogboenfon, is a plant of the family Asteraceae. It is used in traditional medicine for various purposes. There is an important hepatoprotective and healing property, the combination of Allium Sativum/TridaxProcumbens is used to inhibit platelet aggregation. 
From these data, we set ourselves the objective of evaluating the activity of the hydroethanolic extract of the stems and leaves of TridaxProcumbens on the coagulation of blood.

From the results of our study, the hydroethanolic extract of the stems and leaves of TridaxProcumbens gives a yield of $9.92 \%$. We thus note in the leaves a very strong presence of flavonoids, a weak presence of sterol, mucilage and a weak presence of terpene and a strong presence of reducing compounds this is in accordance with the results of Koukouiin 2015, and Ganju in2013. By other research like that of Ikewuchi Jude in 2009 identified other phenolic compounds in TridaxProcumbens extracts such as alkaloids, tannins, carotenoids, saponosides.

The results obtained show that the bleeding time without the extract is $2.58 \pm 0.31 \mathrm{~min}$ while the average bleeding time after treatment with the extract is $1.61 \pm 0.70 \mathrm{~min}$ at a dose of $100 \mathrm{mg} . / \mathrm{kg} \mathrm{PC}$ and $1.77 \pm 0.69 \mathrm{~min}$ at a dose of $300 \mathrm{mg} / \mathrm{kg} \mathrm{PC}$. Thus the extract significantly lowers the bleeding time. These results are comparable to those of Adogo J. L. [35]. Who found that the average bleeding time without the extract is $2.49 \pm 0.09$ and that treated with the extract is $1.40 \pm 0.16 \mathrm{~min}$

Coagulation time decreased in all rats treated with the extract. The coagulation time at D0 is on average $2.85 \pm 0.13 \mathrm{~min}$ at D0 and $2.52 \pm 0.24 \mathrm{~min}$ at D7 for the control rats. For those treated with the extract, the mean clotting time is $2.99 \pm 0$., $16 \mathrm{~min}$ at D0 and $2.44 \pm 0.54 \mathrm{~min}$ at D7 at a dose of $100 \mathrm{mg} / \mathrm{kg} \mathrm{PC}, 2.39 \pm 0.25 \mathrm{~min}$ at D0 and $2.24 \pm 0.29 \mathrm{~min}$ at D7 at a dose of $300 \mathrm{mg} / \mathrm{kg} \mathrm{PC}$. Thus the extract significantly reduces the coagulation time. These results are comparable to those of Kukwa D T [35], who proved that the clotting time decreased steadily as the dosage of the applied extract increased.

We can deduct from the interpretation of fig. 5 that the number of platelets increased. However, in rats treated with tridaxprocumbens extract, the increase in platelet count was considerably elevated in the rats treated with the $300 \mathrm{mg} / \mathrm{kg}$ dose of PC than in those treated with the dose of $100 \mathrm{mg} / \mathrm{kg}$ PC. These results are consistent with those of Z. C. Okoye [35], who have demonstrated a beneficial effect of tridaxprocumbens on blood clotting.

With activated partial thromboplastin time, the results are expressed second to a control. A time inferior to that of the control has no pathological significance. TCA is the coagulation time of a plasma treated under particular conditions.

Fig. 7 shows the effect of tridaxprocumbens on the prothrombin rate. In patients on anticoagulants, the treatment is considered effective when the INR is between 2,4 , and 5 is a rate of prothrombin less than $20 \%$ which is the case of our results. This implies that the intrinsic and extrinsic pathways are ignored. Indeed, the coagulation factors involved in these pathways occur in minute amounts in the blood, unlike prothrombin which occurs in large quantities. It is therefore likely that the extract exerts its procoagulant effect by rapid activation of prothrombin [35].

It is not always possible to have all these exams. In the absence of TCA, TP, TH, fibrinogen assay or platelet count, and if the planned intervention or its immediate consequences reveal a real bleeding risk, at least:

-To achieve a bleeding time at the earlobe (Duke). This test may be an interesting alternative to platelet count. It also informs more generally about primary haemostasis. However, it does not dispense with a study of the coagulation phase.

-To achieve a coagulation time that will allow to roughly quantify the haemorrhagic disorder without being able to define the cause of the disorder.

-To warn the surgeon so that the surgical haemostasis is as careful as possible.

\section{CONCLUSION}

The T. procumbens plant is considered a weed. However, it represents a "pharmacy" plant used for therapeutic purposes in both human and animal health. During this study, carried out in the laboratory of biomembranes and cellular signaling of Abomey Calavi, it was revealed the different chemical groups present in the leaves and stems of Tridaxprocumbens as well as its effect on the coagulation of blood. At the end of our work, we can conclude that our sample contains phenolic compounds, reducing sugars, sterols, terpenes, flavonoids, and mucilages found in the leaves and stems of the plant. The presence of these metabolites in our samples would be responsible for the procoagulant activity of tridaxprocumbens demonstrated in this study. The dose of $100 \mathrm{mg} / \mathrm{kg}$ of body weight would be more appropriate to reduce it and stop the bleeding time and also avoid an increase in activated partial thromboplastin time. The $300 \mathrm{mg} / \mathrm{kg}$ dose of PC would be better for platelet counting, prothrombin activation, reduction in body weight and coagulation time.

The plant material studied in this study is, therefore, a credible alternative for an effective fight against bleeding and also promotes the coagulation of blood.

\section{AUTHORS CONTRIBUTIONS}

All the author have contributed equally

\section{CONFLICT OF INTERESTS}

The authors report no conflicts of interest. The authors alone are responsible for the content and writing of this article.

\section{REFERENCES}

1. Hurtel J. Huiles essentielles et medecine. Phytotherapie, plantes medicinales, aromatherapie, huiles essentielles. Phytomania; 2006.

2. Jahangir M. Chemical and biological studies on some members of asteraceae family and pseudocalymmaelegans, a Native of Brazil. $\mathrm{Ph}$. D. Thesis submitted to the international center for chemical Sciences H. E. J, Research Institute of Chemistry, Univers; 2001.

3. Novais J. Studies on pharmaceutical ethnobotany in Arrabida. Natural Park (Portugal) 2004;93:183-95.

4. Sanogo H, Karadji O, Dembele D. Diallo. Mali Medical 2009;24:1-6.

5. Ali M, Ravinder E, Ramachandran R. A new flavonoid from the aerial parts of tridaxprocumbens. Fitoterapia $2001 ; 72: 313-5$.

6. Mann A, Abdulkadir NU, Muhammad G. Medicinal and economic plants of Nup Land. Juberevans Books and Publication; 2003.

7. Vilwanathan R, Shivashangari KS, Devak T. Hepatoprotective activity of Tridaxprocumbens against d-galactosamine/ lipopolysaccharide-induced hepatitis in rats. J Ethnopharmacol 2005;101:55-60.

8. Tiwari U, Rastogi B, Singh P, Saraf DK, Vyas SP. Immunomodulatory effects of aqueous extract of tridaxprocumbens in experimental animals. J Ethnopharmacol 2004;92:113-9.

9. Durgacharan A Bhagwat, Suresh G Killedar, Rahul S Adnaik. Anti-diabetic activity of leaf extract of tridax procumbens. Int J Green Pharm 2008;2:126-8.

10. Reddipalli Hemalatha. Alteration of plasma lipid profile and atherogenic indices of cholesterol-loaded rats by tridax procumbens linn: implications for the management of obesity and cardiovascular diseases. Int J Green Pharm 2008;2:164-9.

11. Salahdeen HM, Yemitan OK, Alada ARA. Effect of aqueous leaf extract of Tridaxprocumbens on blood pressure and heart rate in rats. Afr J Biomed Res 2004;7:27-9.

12. Chitra Pai, Ujjwala Kulkarni, Manjusha Borde, Sowmya Murali, P Mrudula, Yashwant Deshmukh. Antibacterial activity of Tridax procumbens with special reference to nosocomial pathogens. British J Pharm Res 2011;1:164-73.

13. Rappiah Opong, AK Nyarko, D Dodoo, FN Gyang, KA Karam, NK Ayisi. Ghana Med J 2 Sanogo H, Karadji O, Dembele D, Diallo. Mali Medical 2009;24:1-6.

14. Vishnu Priya P, Radhika K, Sivakumar R, Sri Ramchandra M, Prameela Devi V, Rao Srinivasa. Phytochemical and pharmacological potential of tridax procumbens linn. Int Adv Pharm Sci 2011;2:28-30. 
15. Omedine Koukoui, Cokou P, Agbangnan D, Esperance Medoatinsa, Sylvie Prigent, Oliver Nusse, et al. Chemical profile, cytotoxicity anti-radical and hypolipidemic activities of tridaxprocumbens of Benin. Res J Pharm Biol Chem Sci 2015;6:1441.

16. Pathak AK, Saraf S, Dixit VK. Hepatoprotective activity of tridax procumbent. Fitoterapia 1991;62:307-13.

17. Guinra Alimantou. Rapport de memoire de master en physiologie et application: caractérisation chimique et activités biologiques de Tridaxprocumbens; université d'Abomey-Calavi; 2016.

18. Ahossi P, TJ Dougnon, P Kiki Et, J Houessionon. Synthèse des activités biologiques et de l'utilisation de Tridaxprocumbens en production animale et en médecine traditionnelle review. Int J Biol Chem Sci 2014;8:1476-884.

19. Taddei A, Rosas Romero AJ. Bioactivity studies of extracts from tridaxprocumbens. J Phytomed 2000;7:235-8.

20. Vyas Suresh P, Tiwari Umesh, Rastogi Bhawna, Singh Paramjit. Immunomodulatory effects of aqueous extract of Tridaxprocumbens in experimental animals. Ethnopharmacologoly 2004;92:113-9.

21. Caceres A, Lopez B, Gonzalez S, Beger T, Tada T, Maki J. Plants used in guatemala for the treatement of protozoal infections, 1. Screening of activity to bacteria, fungi and American trypanosomes of native plants. J Ethnopharmacol 1998;62:195202.

22. Chen WH, Ma XM, Wu QX, Shi YP. Chemical constituent diversity of Tridaxprocumbens. Can J Chem 2008;86:892-8.

23. Keerthi Sammeta, Padmaja Kota, Jagadeesh Panda, DVSN Adithya, Swathi Chowdary, A Ram Kumar, et al. Indira antihyperlipidemic activity of ethanolic extract of tridax procumbens l. Int J Pharm Chem Biol Sci 2014;4:874-7.

24. Suseel L, Sarsvathy A, Brindha P. Pharmacolognostic studies on tridaxprocumbens L. J Phytol Res 2002;15:141-2.

25. Agban A, Gbogbo KA, Amana EK, Tegueni K, Batawila K, Koumaglo K, et al. Évaluation des activités antimicrobiennes de tridaxprocumbens (asteraceae), jatrophamultifida (euphorbiaceae) et de chromolaenaodorata (asteraceae). Eur Sci J 2013;9:278-90.

26. Makkar HPS. Effects and fate of tannins in ruminant animals, adaptation to tannins, and strategies to overcome detrimental effects of feedingtannin-rich feeds. Small Ruminant Res 2003;49:241-56.

27. Aboh AB, Olaafa M, Dossou Gbete GSO, Dossa AD, Djagoun N. Ingestion volontaire et digestibilité apparente d'une ration à base de la farine de graines de mucunapruriens var. utilis completee de fourrages chez les lapins. Tropicultura 2002; 20:165-9.

28. Babatounde S, Sidi H, Houinato M, Oumorou M, Mensah GA, Sinsin BA. Valeuralimentaire des fourrages consommés parles taurillons Borgou sur les parcours naturels du centre du Bénin. Int J Biol Chem Sci 2011;5:2382-94.

29. Anil Saini, Harish Kumar Soniand, Parvesh Gupta. A review on tridax procumbens imperial. IJIR 2016;2:2454-1362.

30. Nia R, Paper DH, Essien EE, Oladimeji OH, Iyadi KC, Franz G. Investigation into in vitro radical scavaging and in vivo antiinflammatory potential of Tridaxprocumbens. Nig J Physiol Sci 2003;18:39-43.

31. Amagbegnon, rapport de memoire de master en physiologie et application: evaluation de lactivite preventive et therapeutique de tridaxprocumbenssur lobesite lhyperglycemie et la dyslipidemie provoquee chez les rats wistar: Universite $\mathrm{d}$ Abomey-Calavi; 2017.

32. Kumar SS, Asokan D, Kumar PS, Kalavathy S, Manoharan N. Salubrious effect of Tridaxprocumbens on paracetamol hepatotoxicity. Int J Pharma Sci 2001;63:64-6.

33. Habila JD, Bello IA, Dzikwi AA, Musa H, Abubakar N. Total phenolics and antioxidant activity of tridaxprocumbens linn. Afr J Pharm Pharmacol 2010;4:123-6.

34. Ikewuchi CJ, Ikewuchi CC, IgbohNgozi M. Chemical profile of tridaxprocumbens linn. Pak J Nutr 2009;8:548-50.

35. Ikese CO, Okoye ZC, Kukwa DT, Adoga SO, et Lenka JL. Effet de l'extrait de feuilles aqueuses de tridax procumbens sur la coagulation du sang. Int J Pharm Sci Res 2015;6:3391-5. 